\title{
Галина Русин,
}

кандидат педагогічних наук, доцент

кафедри педагогіки початкової освіти, ДВНЗ «Прикарпатський національний університет імені Василя Стефаника» (м. Івано-Франківськ, Україна)

\author{
Halyna Rusyn, \\ $\mathrm{PhD}$ in Education, Associate Professor, \\ Department of Pedagogy of Primary Education, \\ Vasyl Stefanyk Precarpathian National University \\ (Ivano-Frankivsk, Ukraine) \\ grusyn@gmail.com \\ ORCID ID 0000-0001-9601-5466
}

УдК 37.013.37

\section{ВПЛИВ СОЦІОКУЛЬТУРНОГО СЕРЕДОВИЩА НА ФОРМУВАННЯ ВИХОВНИХ КОНЦЕПЦІЙ РОДИННОЇ ЕТНОПЕДАГОГІКИ}

\begin{abstract}
Анотація. Авторка розглядає народну педагогіку як один із основних чинників створення виховної системи в сучасній українській школі та її подальшого розвитку, формування високоосвіченої, духовно багатої і морально стійкої особистості, вихованої на народних цінностях, звичаях, традиціях, рідній культурі, що є найголовнішим для молоді під час її етноідентифікації та входження в український соціум. Автором окреслено, що саме сім'я виступає сферою формування ідеалів, світогляду, інтересів, первинних ціннісних орієнтацій та розвиває соціальні спрямування дитини. Завдання сучасної освіти - підготовка педагогічної культури батьків, забезпечення їх знаннями, володінням ефективними засобами і методами розвитку свідомості і поведінки дитини. Найпершим засобом регулювання взаємин $€$ встановлення емоційно-ціннісного спілкування в сім'ї. Міжособистісне спілкування в сім'ї допомагає утверджувати доброзичливі, правдиві і щирі стосунки з дітьми, розвивати і збагачувати сімейні традиції і звичаї, виховувати дітей на позитивних прикладах родини. Водночас сім'я задовольняє і найважливіші особистісні потреби, значення яких постійно зростає. Серед них - потреба в довірливому спілкуванні, співпереживанні, співучасті. Саме підвищення педагогічного рівня батьків дасть змогу перетворити сімейне виховання на цілеспрямований, успішний процес, що повноцінно розв'яже завдання розвитку і виховання дитини.
\end{abstract}

Ключові слова: соціокультурне середовище, спілкування, сім'я, педагогічна культура батьків.

\section{INFLUENCE OF SOCIOCULTURAL ENVIRONMENT ON THE FORMATION OF EDUCATIONAL CONCEPTS OF FAMILY ETHNOPEDAGOGY}

Abstract. In this study the author considers folk pedagogy as one of the main factors for creating an educational system in the modern Ukrainian school and its further development and formation of a highly educated, spiritually rich and morally stable personality brought up on national values, customs, traditions and native culture, which is the most important for youth during their ethnic identification and entry into the Ukrainian society. The author outlines that it is the family that acts as the sphere of forming ideals, world view, interests, primary value orientations and develops the child's social aspirations. The task of modern education is to prepare the pedagogical culture of parents and provide them with knowledge and possession of effective means and methods of developing the child's consciousness and behavior. The very first way to regulate relationships is to establish emotional and value communication in the family. Interpersonal communication in the family helps to establish friendly, truthful and sincere relationships with children, develop and enrich family traditions and customs and raise children on positive examples of the family. At the same time the family meets the most important personal needs, the importance of which is constantly growing. Among them is the need for trustful communication, empathy and participation. That is why parents should pay more attention to their children and communicate with them more actively if it is possible.It is the increase of the pedagogical level of parents that will make it possible to turn family upbringing into a goal controlled, successful process of development and upbringing of the child. The pedagogical culture of parents is a set of knowledge, emotional manifestations and skills of psychological and pedagogical nature, which provide the activities, education and development of the child. Knowledge of age and individual characteristics of the child, patterns and stages of his mental and physical development, needs, interests and values. Pedagogical culture of parents is a personal education, which is expressed in a value-oriented orientation parents for the full upbringing and development of the child, the ability to reflect, self-control, regulation of their behavior, creative mastery of psychological and pedagogical technology, knowledge, humanistic style of interaction with the child.

Keywords: sociocultural environment, communication, family, parents' pedagogical culture. 


\section{ВСТУП}

Постановка проблеми. Соціально-економічні трансформації в Україні: активний розвиток ринкової економіки, демократизація суспільної думки, гуманізація навчально-виховного процесу, розвиток духовного й інтелектуального потенціалу нації - зумовлюють зміни і в царині педагогічної науки, з'являються якісно нові вимоги щодо виховання сучасного юнацтва. За таких умов посилюється необхідність вивчення історичного досвіду, проведення ретроспективного аналізу розвитку освіти, виховання. Через вивчення народної педагогіки, етнопедагогіки, родинної педагогіки сучасне покоління може досягти поставленої мети. Саме етнопедагогіка як наука посідає проміжне місце в системі науково-педагогічних знань.

Стратегічною метою української освіти є створення оптимальних умов щодо виховання молодої людини нового типу, що володіє цілісним сприйняттям світу, прагне до постійного духовного зростання й є суб'єктом власної діяльності. У психолого-педагогічній літературі суб'єктність розуміється як інтегративна соціальнопсихологічна якість, свідома діяльність особистості та її діяльне ставлення до самої себе й світу, що, будучи взаємозумовленими, визначає та характеризує ступінь суб'єктного впливу особистості на середовище (Паламарчук Л.Б, 2013, с. 32), у той час, як соціально-культурне середовище, своєю чергою, виступає джерелом розвитку людини.

Аналіз наукових досліджень і публікацій. Питання та проблеми родинного виховання висвітлені в працях Т. Алєксєєнко, О. Вишневського, В. Костіва, В. Кузя, О. Любара, В. Постового, В. Струманського, М. Стельмаховича, Н.Лисенко, П. Щербаня та ін. Особливого значення як вихідні положення набувають погляди на родинне виховання, відображені в працях вітчизняних корифеїв педагогічної думки, педагогів-практиків. Виховання дітей у сім'ї належить до найдавніших проблем, розв'язати які людство прагнуло впродовж багатьох історичних періодів.

META I ЗАВДАННЯ ДОСЛІДЖЕННЯ - розкрити вплив соціокультурного середовища на формування виховних концепцій родинної етнопедагогіки в сучасному виховному (освітньому) просторі.

МЕТОДИ ДОсЛІДЖЕНнЯ: на основі теоретичного узагальнення та аналізу педагогічної, психологічної літератури подано характеристику проблемного поля дослідження і з'ясовано сутність педагогічної культури батьків у формуванні виховних концепцій родинної етнопедагогіки.

\section{РЕЗУЛЬТАТИ ДОСЛІДЖЕННЯ}

Середовище, що є сукупністю природних і соціальних умов, у яких функціонує людське суспільство, виступає стосовно особистості як необхідна умова її становлення і розвитку. У процесі набуття та засвоєння соціального досвіду людства особистість включається в процес спілкування і стосунки з людьми, які їі оточують, явищами, речами, розвиває певну соціальну діяльність. Свідомість, духовний світ людини формується всім устроєм життя, певним соціальним середовищем, що діє в сукупності з вихованням.

Соціальне середовище і особистість постійно перебувають у взаємодії: середовище впливає на особистість, сприяє її формуванню; особистість, що діє в соціальному середовищі, вступає в стосунки з іншими особистостями, бере участь у діяльності різних спільнот, створює це середовище, надає йому певної соціальної якості. Соціокультурне середовище можна розглядати як систему, що не тільки безпосередньо впливає на розвиток особистості, але й опосередковано визначає характер і спрямованість різних форм державного, суспільного, родинного, інституційного та неформального виховання. Отже, соціокультурне середовище є чинником виникнення і розвитку нових тенденцій у вихованні.

Українські педагоги Є. Сявавко, О. Вишневський стверджують, що саме занурення в народну педагогіку, яка утворює цілісну складну систему, має свої ідеали, принципи й традиційні засоби (Сявавко Є.І., 1974, с.43), є тим новим зерном виховання молодого покоління. Народна мудрість відрізняється автентичністю й природовідповідністю (Вишневський О.,1996, с.14). Вона носить колективний характер. Творчість, традиції та звичаї становлять основу виховної системи етносу. Для педагогів, батьків важливо правильно відтворювати та застосовувати засоби народного виховання в процесі повсякденного спілкування з дітьми. Педагоги та психологи дійшли одностайного рішення, що найважливіший чинник - це спілкування.

Спілкування $€$ необхідною умовою існування людини. Воно включає всю різноманітність духовних і моральних форм життєдіяльності, є одним з основних засобів і джерел психологічного розвитку. Потреба в спілкуванні має загальнолюдський характер і є однією з фундаментальних вищих соціальних потреб людини в історії.

Останнім часом у зв'язку зі збільшенням ролі людського чинника в розвитку суспільства феномен спілкування активно досліджують науковці - суспільствознавці, філософи, соціологи, психологи, педагоги. Учені вбачають у цій проблемі саме той вузол запитань, які неможливо обійти, розв'язуючи завдання, що стоять перед сім'єю, школою, громадськістю, виконуючи соціальне замовлення держави на виховання вільної, свідомої, активної особистості.

У науці немає єдиного підходу до вивчення спілкування. Спілкування розглядається як вид людської діяльності, її компонент, невід'ємний атрибут; складне явище комунікації, діяльності, стосунків; персоніфікована форма суспільних відносин, їхня особистісна форма; явище, тісно пов'язане з соціальними відносинами, яке розглядається в єдності з відображенням і зверненням; специфічна форма спільної діяльності; специфічна система міжособистісних взаємозв'язків тощо.

Різноманітні підходи до дослідження спілкування зумовлюють різні трактування самого поняття «спілкування», проте більшість учених розглядає спілкування як специфічний засіб взаємодії та взаємовпливу людей один на одного. 3 допомогою комунікації відбувається обмін інформацією, а також процес взаємного двостороннього 
розвитку й формування світогляду, поглядів, почуттів і переконань, установок і поведінки, тобто духовне й моральне становлення особистості загалом. 3 такою думкою науковців погоджуємося і ми.

Науковці визначають такі функції спілкування:

- комунікативну - забезпечує зв'язки між людьми;

- інформативну - сприяє духовному збагаченню людей знаннями, уміннями й навичками;

- психотерапевтичну - дає можливість обдарованим і підготовленим індивідам оздоровчо впливати на інших;

- гедоністичну - забезпечує відчуття людиною в процесі спілкування духовного задоволення , насолоди;

- морально-етичну - духовне задоволення гуманними вчинками, переживання почуття краси;

- релігійну - забезпечення колективної та особистої взаємодії з (Богом) від автора (Абсолютом ) на основі віри в безсмертя душі, надії на спасіння (Костів В., Ковбас Б., 2002, с.108).

3 раннього віку дитина відчуває потребу в спілкуванні. Вона своєю поведінкою вимагає до себе уваги (вередує безпідставно), потребує постійної присутності дорослих (варто підійти та заговорити до дитина, посміхнутись, доторкнутись до неї, як дитина затихає і відповідає на це).

Отже, потреба в спілкуванні проявляється в дитини й задовольняється на цьому етапі головним чином спілкуванням з матір'ю, родиною, що проживають у сім'ї. Психологи стверджують, що в разі недостатньої уваги як розумовий, так й фізичний розвиток дитини сповільнюються. Потреба найбільшого спілкування для дитини,на думку психологів, дуже важлива в ранньому віці і до трьох років; ця потреба, окрім інтенсивного спілкування з дорослими, передбачає постійний тісний контакт з якоюсь однією особою (матір'ю, батьком).

Соціально-педагогічна ситуація в сучасній поліетнічній Україні об'єктивно непроста і неоднозначна для інтегрування етнопедагогічних здобутків у зміст освіти майбутнього громадянина без урахування його причетності до певного етнокультурного поля.

У праці «Сучасне українське виховання» О. Вишневський визначає одним із етапів розвитку особистості - етнічне усвідомлення, що «являється першоосновою, коріння патріотизму. Етнізація дитини починається з раннього періоду життя в сім'ї, маминої колискової, з бабусиної казки, з участі у народних звичаях та обрядах, із народної пісні, причетності до народної творчості. У ранньому дитинстві формується культ рідної оселі, сім'ї, предків, рідного села, міста. Фундаментальне значення в процесі етнізації має рідна мова, засвоєння якої до певного часу не повинні заважати інші мови» (Вишневський О.,1996, с. 138).

Взаємодія сім'ї та школи у процесі розвитку особистості дитини є іще одним з основних компонентів. В. Сухомлинський - один з тих педагогів, який розглядав проблему єдності сім'ї, громадськості та їх вплив на розумове, трудове, моральне, естетичне та фізичне виховання. Правильно оцінюючи тенденції розвитку сучасної школи, він висновує, що «подальший розвиток суспільного виховання не може відбуватися без більш активної і безпосередньої участі сім'ї, батьків. Мова йде не про епізодичну допомогу школі з боку сім'ї, а про комплекс спільних цілеспрямованих дій школи і сім'ї на особистість, про те, щоб виховання дітей становило важливий громадський обов'язок сім'ї, було виконанням їх обов'язку перед суспільством» (Сухомлинський В. О., 1977, с. 38).

Нові історичні умови створили ґрунт для того, щоб розглядати виховання у школі і сім'ї як єдину систему. В. Сухомлинський висвітлював у численних працях питання шкільної і батьківської педагогіки. Він вважав, що проблема шкільно-сімейного виховання - одна з найважливіших проблем, над якою необхідно працювати педагогами і батькам у теоретичному і практичному плані, оскільки «шкільно-сімейне виховання не тільки дає змогу добре виховувати молоде покоління, але й одночасно є дуже важливою умовою вдосконалення морального обличчя сім'ї, батька і матері. Без виховання дітей, без активної участі батька і матері в житті школи, без постійного духовного спілкування і взаємного духовного збагачення дорослих і дітей неможлива сама сім'я як первинний осередок суспільства, неможлива школа як найважливіший навчально-виховний заклад і неможливий моральний прогрес суспільства» (Сухомлинський В. О., 1977, с. 45).

Сімейна педагогіка об'єднує в собі багато цінного, що не завжди можна реалізувати за умов шкільного виховання.

Якщо у школі в процесі виховання переважають елементи змістові, то в сім'ї - емоційні. Жоден навчальний заклад не може прищепити дитині таких якостей, які формує сім'я.

Вимогливість - один з важливих методів педагогічної взаємодії, але він дає позитивні результати тільки тоді, коли передбачає повагу до особистості дитини, це як принциповість, такт, довіра, справедливість та опора на позитивне. Педагог звертає увагу на важливість авторитету батьків.

Підготовка батьків до виховної діяльності передбачає високий рівень їхньої педагогічної культури, який залежить від освіти, умінь і навичок виховання дітей, психолого-педагогічних, фізіолого-гігієнічних та правових знань, від ставлення до педагогічної діяльності, від рівня розвитку педагогічних здібностей.

Співпраця батьків і педагогів у формуванні моральних якостей юнацтва знайшли місце в працях Івана Огієнка (Митрополита Іларіона), у яких - відповіді на важливі запитання, які хвилюють сьогодні батьків як організаторів виховання дітей та молоді у власних родинах. Та донести їх до батьків, порадити, як розв'язати ті чи інші проблеми у виховній роботі, мають педагоги. Вони повинні включити в коло ситуацій, які розглядають з батьками, уміння забезпечувати життєдіяльність кожної конкретної родини; ведення господарства, оформлення житла, розрахунок коштів роди тощо. Адже розвиток особистості тісно пов'язаний з добробутом, сімейною атмосферою, взаєминами, 
способом життя всієї родини та її здатністю виховувати дітей. 3 погляду суспільства батьки зобов'язані задовольняти потреби дітей, дбати про їх загартування, психологічний та інтелектуальний розвиток.

Вплив культури на індивідуальний характер, на ментальність та вдачу людини відбувається в ранньому віці через родину, що відтворює культурне середовище етногрупи. Те, що є спільною у способі родинного виховання, і формує певні риси національного характеру, це спільне не вичерпується конкретними вказівками й порадами дитині, воно виявляється у традиціях і нормах даної культури, що їх персоніфікують батьки. «3 «інтроекцією» своєрідного родинного стилю життя у глибинне несвідоме дитини входить певна система вартостей, якої вона дотримується впродовж життя. Пізніше культурні впливи торкаються здебільшого поверхні психіки. 3 такого погляду національний характер постає «продуктом певної культури і водночас, персоніфікуючись, носієм її, продовжувачем культурних традицій і норм у наступних поколіннях» (Родинна педагогіка, 2002, с. 151).

Педагогічний потенціал родини включає формування в дітей уявлень про взаємини й виконання рольових функцій членів сім'ї, специфіку сімейного виховання, педагогічний такт батьків, шляхи підвищення етнопедагогічної культури, усвідомлення емоційного стану своєї дитини, а також озброєння дітей конкретними знаннями й уміннями з основ самовиховання. Безперечно, батьки повинні володіти певними психолого-педагогічними знаннями, які включають знання розвитку особистості дитини, задоволення потрібності-мотиваційної сфери, знання прояву батьківських почуттів, методів впливу на дитину. Знання народних традицій, обрядів, звичаїв, усної народної творчості, української народної культури, що збагатить виховний процес у будь-якій сім'ї.

Сучасні дослідження свідчать, що потрібно насамперед формувати емоційну сферу дитини. Саме через міжособистісні контакти у сім'ї формується діапазон емоційних проявів - таких як почуття, як радість, захоплення, порив, сум, тривога, сором, гнів, обурення, ніяковість (М. Буянов, А. Захаров та ін.).

Педагогічна підготовка батьків є основним компонентом етнопедагогічної культури.Важливе значення у вихованні мають міжсімейні родинні зв'язки, де дитина переймає досвід старших поколінь.

Система вироблених і прийнятих українським народом принципів, методів, форм і прийомів виховання дітей та юнацтва передається від одного покоління до іншого й засвоюється ними через певні духовно-моральні цінності та настанови, національні звичаї і традиції, знання, уміння та навички, набуті в процесі життєдіяльності родини. Звідси необхідним постає обґрунтування передачі відповідних усталених виховних норм, зразків, звичаїв через формування високої педагогічної культури батьків, які зумовлюють певну спрямованість поведінки, певну духовно-моральну мотивацію дій своїх вихованців. Яким же чином можна підвищити рівень етнопедагогічної культури сучасних батьків? До прикладу, у статті «Закономірності розвитку етнопедагогічної культури батьків» В. Костів пропонує враховувати всі помилки в аналізі організації педагогічного навчання батьків та випрацювати в практичній діяльності основні принципи:

- принцип професійної компетентності, що означає необхідність підготовки всіх причетних до справи педагогічної освіти батьків для розв'язання проблем сімейної педагогіки;

- принцип діагностичного підходу означає необхідність поєднання педагогічної освіти батьків із вивченням сім'ї, виявленням і самовиявленням її реальних виховних можливостей та рівня педагогічної культури кожного з дорослих членів сім'ї;

- принцип диференційованого підходу вказує на необхідність урахування типології сімей, створення такої системи підвищення педагогічної культури, включаючись у яку батьки могли б вільно до своїх проблем, інтересів, вибрати зміст і відповідну форму для її вдосконалення;

- принцип спрямованості педагогічної освіти батьків на особистість дитини, її індивідуальний творчий розвиток, який допоможе програмувати ціннісні орієнтації батьків із питань виховання в доцільному напрямі;

- принцип індивідуального підходу підвищення педагогічної культури та інтересу до виховання своїх дітей до такого рівня, який характеризується складанням індивідуальних сімейних виховних програм (Костів В., Ковбас Б., 20202, с. 174-176).

\section{ВИСНОВКИ ТА ПЕРСПЕКТИВИ ПОДАЛЬШИХ ДОСЛІДЖЕНЬ}

Проблема формування педагогічної культури батьків набуває особливої актуальності як важлива умова ефективності та якості партнерської взаємодії дітей з батьками. Питання освіти дітей та захисту їх інтересів, партнерської взаємодії з батьками висвітлено в положеннях законів України та інших підзаконних нормативноправових актів.

Формування педагогічної культури батьків учнів потребує розв'язання суперечностей між зростанням потреб сучасного суспільства у формуванні педагогічної культури батьків та недостатністю психолого-педагогічних напрацювань, інформаційно-просвітницької роботи з означеного питання; недостатньою педагогічною компетентністю батьків, зокрема, готовністю оволодіти інформацією й розширити досвід упровадження найкращих практик, форм, методів і прийомів сімейного виховання.

Отже, щоб досягнути етнопедагогічної культури батьків, передовсім потрібно перезавантажити навчальновиховний процес у загальноосвітніх навчальних закладах, підготувати висококваліфікованих спеціалістів. Маємо надію, що Концепція «Нової української школи» допоможе втілити нові принципи, методи, форми роботи в нову школу. 


\section{СПИСОК ВИКОРИСТАНИХ ДЖЕРЕЛ}

Вишневський О. Сучасне українське виховання. Педагогічні нариси. Львів: лОПТ ім. Г.Ващенка, 1996. 238 с.

Костів В., Ковбас Б. Родинна педагогіка: у 3-х т. Т.1. Основи родинних взаємовідносин. Івано-Франківськ, 2002.255 с.

Костів В., Ковбас Б. Родинна педагогіка: у 3-х т. Т.2. Основи родинного виховання. Івано-Франківськ, 2002. 250 с.

Родинна педагогіка: навч.-метод. посібник / за ред. Марушкевич А., Постовий В., Алєксєєнко Т. та ін. Київ: ПАРАПАН, 2002.216 с.

Паламарчук Л.Б. Хрестоматія з етнопедагогіки : навч. посіб. для студ. вищ. навч. закладів / уклад.: Л.Б. Паламарчук, Т.О. Горохова. К. : ун-т ім. Б. Грінченка, 2013. 416 с.

Сявавко Є.І. Українська етнопедагогіка в її історичному розвитку. Київ:, 1974. 233 с.

Сухомлинський В.О. Серце віддаю дітям. Вибрані твори. Київ, 1977. 88 с.

\section{REFERENCES}

Vyshnevsky O. (1996) Modern Ukrainian education. Pedagogical essays.

Lviv: BALL

Kostiv V., Kovbas B. (2002) Family pedagogy: in 3 volumes Vol.1. Fundamentals of family relationships. Ivano-Frankivsk.

Kostiv V., Kovbas B.(2005) Family pedagogy: in 3 volumes Vol.2. Fundamentals of family education. Ivano-Frankivsk.

Family pedagogy: teaching method. manual (2002)/ ed. Marushkevych A., Postovy V., Alekseenko T. and others. K. PARAPAN.

Palamarchuk L.B. (2013) Textbook of ethnopedagogy: textbook. way. for students. higher textbook institutions / compiled by: L.B. Palamarchuk, TO Peas. K .: Univ. B. Grinchenko.

Syavavko E.I . (1974) Ukrainian ethnopedagogy in its historical development. K.

Sukhomlinsky V.O. (1977) I give my heart to children. Selected works. K. 